\title{
Utilization of Kalpataru Flower Extract (Hura crepitans Linn) as an Alternative Acid Base Indicator
}

\author{
*Bayu Riswanto \& Sitti Aminah \\ Pendidikan Kimia/FKIP - Universitas Tadulako, Palu - Indonesia 94119 \\ Received 11 June 2020, Revised 08 July 2020, Accepted 06 August 2020 \\ doi: 10.22487/j24775185.2020.v9.i3.pp148-157
}

\begin{abstract}
Kalpataru flower (Hura crepitans Linn) is an anthocyanin-containing plant. This study aims to utilize extract from the kalpataru flower as an alternative acid base indicator and determine the type of acid-base titration suitable for extracting the kalpataru flower indicator. Kalpataru flowers are macerated with methanol solvent for around 2 bours. Kalpataru flower extract was tested as an indicator in acid-base solution, buffer, and compared with phenolphthalein and methyl orange for acid-base titration, namely: strong acids with strong bases, weak acids with strong bases, and weak bases with strong acids. The results obtained in this study were: indicator extract of brownish yellow kalpataru flowers, in strong red acids, in strong bases of dark green, in weak pink acids, and in weak bases in light green. In the buffer, the indicator extract of the kalpataru flower has a range of $p H$ pH 4-5 (pink-colorless) and $p H$ 9-11 (yellowish green-dark green). The indicator of kalpataru flower extract can be used on strong acid titration with strong bases, weak acids with strong bases and weak bases with strong acids. Kalpataru flower extract can be used as an acid-base indicator.
\end{abstract}

Keywords: Alternative acid-base, kalpataru flower, extract indicator

\section{Pendahuluan}

Asam dan basa merupakan dua golongan zat kimia yang sangat penting dalam kehidupan sehari-hari. Sifat asam basa, larutan dikelompokkan kedalam tiga golongan yaitu bersifat asam, bersifat basa dan bersifat netral. Teori Arrhenius menyatakan asam adalah senyawa yang dapat melepas ion hidrogen $\left(\mathrm{H}^{+}\right)$jika dilarutkan dalam air, sedangkan basa merupakan senyawa yang dapat melepaskan ion hidroksida $\left(\mathrm{OH}^{-}\right)$jika dilarutkan dalam air. Sifat asam dan basa suatu zat dapat diketahui dengan menggunakan sebuah indikator. Indikator asam basa adalah suatu senyawa organik yang dapat berubah warna dengan berubahnya $\mathrm{pH}$, biasanya digunakan untuk membedakan suatu larutan yang bersifat asam atau basa dengan cara memberikan perubahan warna yang berbeda pada larutan asam dan basa (Fessenden \& Fessenden, 1999).

Indikator asam basa yang sering digunakan yaitu kertas lakmus, fenoftalein, metil merah, dan brom timol biru. Indikator ini biasanya dikenal dengan indikator sintetik. Indikator sintetik memiliki beberapa kelemahan seperti polusi kimia, ketersediaan dan biaya produksi yang tinggi (Nuryanti dkk., 2010). Oleh karena itu diperlukanlah indikator alternatif (indikator alami) yang mudah diperoleh dan ramah lingkungan. Indikator alami merupakan jenis indikator yang memanfaatkan tumbuhan berwarna sebagai bahan dasarnya baik berupa batang, daun, bunga dan buah. Akan tetapi tidak semua tumbuhan dapat memberikan perubahan warna yang signifikan pada kondisi asam maupun basa. Beberapa indikator alami dapat dibuat dari bunga sepatu (Hibiscus rosa sinensis L) (Nuryanti dkk., 2010). Bunga karamunting (Ochtchocharis bornensis BI) (Indira, 2015) dan bunga belimbing wuluh (Averboa bilimbi L) (Lestari, 2016) karena mengandung senyawa pemberi pigmen warna yaitu antosianin.

Tanaman kalpataru (Hura crepitans Linn) merupakan salah satu jenis tanaman hutan kota yang tidak banyak dikenal oleh masyarakat luas. Umumnya tanaman kalpataru di kota Palu hanya digunakan sebagai tanaman hias dan peneduh sehingga pemanfaatannya belum dapat dikatakan maksimal. Berdasarkan penelitian Agustiani (2015) hasil uji fitokimia yang telah dilakukan menunjukkan bahwa tanaman kalpataru juga mempunyai kandungan senyawa kimia yang bermanfaat meliputi saponin, tanin, flavonoid, serta steroid. Oleh karena itu peneliti tertarik untuk melakukan penelitian terhadap bagian bunga tanaman kalpataru (Hura crepitans Linn) yang sepengetahuan belum pernah diteliti dan memiliki potensi untuk dijadikan bahan penelitian sebagai indikator asam basa alternatif karena diindikasikan mengandung antosianin.

Antosianin merupakan zat pewarna alami yang tergolong kedalam benzopiran. Struktur utama turunan benzopiran ditandai dengan adanya dua

*Correspondence:

Bayu Riswanto

e-mail: bayuriswanto54@gmail.com

(c) 2020 the Author(s) retain the copyright of this article. This article is published under the terms of the Creative Commons Attribution License 4.0, which permits unrestricted non-commercial use, distribution, and reproduction in any medium, provided the original work is properly cited. 
cincin aromatik benzena $\left(\mathrm{C}_{6} \mathrm{H}_{6}\right)$ yang dihubungkan dengan tiga atom karbon yang membentuk cincin (Moss, 2002). Struktur antosianin mempunyai delokasi yang dapat diperpanjang akibat pengaruh basa (kenaikan $\mathrm{pH}$ ) membentuk anhidrobase sehingga terjadi perubahan warna. Perubahan bentuk struktur yang menyebabkan terjadinya perubahan warna ada kemiripan dengan indikator fenolftalein (Nuryanti dkk., 2010). Antosianin pada $\mathrm{pH}$ 1,0 berbentuk kation flavilium yang berwarna merah muda, sedangkan pada $\mathrm{pH} 4.5$ antosianin berbentuk basa quinoidal yang berwarna ungu muda. Struktur antosianin lebih stabil pada $\mathrm{pH}$ berkisar 1 dan 3, sedangkan pada $\mathrm{pH}>4$ struktur antosianin tidak stabil. Hal ini disebabkan dalam keadaan asam struktur dominan antosianin berada dalam bentuk kation flavilium terprotonisasi dan kekurangan elektron (Bridgers dkk., 2010).

Ekstraksi antosianin dapat dilakukan dengan beberapa jenis solven, seperti air, etanol, metanol tetapi yang paling efektif adalah dengan menggunakan metanol. Berdasarkan penelitian Dewi dkk. (2002) ekstraksi dedak sorgum dengan berbagai jenis pelarut hasil terbaik ditunjukkan dengan pelarut metanol memiliki kadar antosianin tertinggi yaitu $1.546 \mathrm{mg} / \mathrm{g}$. Suhu dan $\mathrm{pH}$ berpengaruh terhadap efisiensi ekstraksi antosianin dan koefisien difusinya, semakin rendah $\mathrm{pH}$ maka koefisien distribusi semakin tinggi, demikian juga semakin tinggi temperaturnya. Tetapi antosianin merupakan senyawa fenolik yang labil dan mudah rusak akibat pemanasan, sehingga berakibat pada penurunan bioaktivitasannya (Perry, 1999). Antosianin merupakan pembentuk dasar pigmen warna merah, ungu dan biru pada tanaman.

Penelitian ini diharapkan pula dapat menjadi media dan referensi yang membantu proses pembelajaran kimia khususnya materi asam basa dengan memanfaatkan bahan-bahan alami sekitar sebagai alternatif indikator asam-basa di sekolahsekolah.

\section{Metode}

Alat yang digunakan dalam penelitian ini yaitu gelas ukur, gelas kimia, spatula, $\mathrm{pH}$ meter, batang pengaduk, labu ukur, Erlenmeyer, buret, pipet tetes, pipet volume, shacker, plat tetes, corong buchner, neraca digital, baskom, stopwatch, aluminium foil, botol semprot, saringan teh, tabung reaksi, penangas listrik, termometer, statif dan klem.

Bahan yang digunakan dalam penelitian ini adalah bunga kalpataru (Hura crepitans Linn), kertas saring, aquades, larutan $\mathrm{HCl} 0.1 \mathrm{M}, \mathrm{NaOH} 0.1 \mathrm{M}$, $\mathrm{NH}_{4} \mathrm{OH}$ 0.1 M, $\mathrm{CH}_{3} \mathrm{COOH} 0.1 \mathrm{M}$, larutan $\mathrm{HCl} 2$ M, larutan $\mathrm{NaOH} 2 \mathrm{M}$, larutan buffer $\mathrm{pH}$ 1-12, indikator metil orange, fenoftalein, asam oksalat dan metanol.

\section{Ekstraksi Bunga Kalpataru}

10 gram bunga kalpataru (Hura crepitans Linn) yang bersih dimasukkan ke dalam Erlenmeyer dan ditambahkan pelarut metanol $100 \mathrm{~mL}$, lalu dishaker dan dimaserasi selama \pm 2 jam. Campuran kemudian didekantasi dan disaring agar diperoleh hasil ekstraksi yang siap digunakan sebagai indikator asam basa.

\section{Uji Kualitatif Antosianin}

$10 \mathrm{~mL}$ ekstrak dimasukkan ke dalam masing masing tabung reaksi yang berbeda. Kemudian pada tabung reaksi I ditambahkan tetes demi tetes larutan $\mathrm{HCl} 2 \mathrm{M}$ lalu dipanaskan pada suhu $100{ }^{\circ} \mathrm{C}$ selama 5 menit. Hasil positif bila timbul warna merah. Sedangkan pada tabung reaksi II ditambahkan tetes demi tetes $\mathrm{NaOH}$ sambil diamati perubahan warna yang terjadi. Hasil positif bila timbul warna hijau biru yang memudar perlahanlahan (Putri dkk., 2015).

\section{Pengujian Ekstrak Indikator Bunga Kalpataru pada Larutan Asam Basa}

Ekstrak bunga kalpataru yang diperoleh dimasukkan 2 tetes ke dalam plat tetes dan diuji dengan masing-masing larutan $\mathrm{HCl} 0.1 \mathrm{M}, \mathrm{NaOH}$ $0.1 \mathrm{M}, \mathrm{CH}_{3} \mathrm{COOH} 0.1 \mathrm{M}$, dan $\mathrm{NH}_{4} \mathrm{OH} 0.1 \mathrm{M}$. Diamati perubahan warna yang terjadi.

\section{Pengujian Ekstrak Indikator Bunga Kalpataru pada Larutan Buffer pH 1-12}

Ekstrak bunga kalpataru yang diperoleh dimasukkan 2 tetes ke dalam plat tetes dan diuji dengan larutan buffer $\mathrm{pH}$ 1-12. Diamati perubahan warna yang terjadi.

\section{Pengujian pada Titrasi Asam Basa}

\section{Titrasi Asam Kuat dan Basa Kuat}

$20 \mathrm{~mL}$ larutan $\mathrm{HCl} 0.1 \mathrm{M}$ dimasukkan ke dalam Erlenmeyer kemudian ditambahkan 5 tetes ekstrak bunga kalpataru hingga larutan berubah warna. Dititrasi dengan larutan $\mathrm{NaOH} 0.1 \mathrm{M}$ hingga terjadi perubahan warna. Titrasi dilakukan sebanyak 3 kali dan mencatat volume titer yang digunakan. Setiap penambahan $2 \mathrm{~mL}$ titer, diukur nilai $\mathrm{pH}$ campuran menggunakan $\mathrm{pH}$ meter hingga terjadi perubahan warna. Selanjutnya titrasi ini diganti dengan mengganti ekstrak bunga kalpataru dengan indikator fenoftalein sebagai pembanding.

\section{Titrasi Asam Lemah dan Basa Kuat}

$20 \mathrm{~mL}$ larutan $\mathrm{CH}_{3} \mathrm{COOH} \quad 0.1 \mathrm{M}$ dimasukkan ke dalam Erlenmeyer kemudian ditambahkan 5 tetes ekstrak bunga kalpataru hingga larutan berubah warna. Dititrasi dengan larutan $\mathrm{NaOH}$ 0.1 M hingga terjadi perubahan warna. Titrasi dilakukan sebanyak 3 kali dan mencatat volume titer yang digunakan. Setiap penambahan 2 $\mathrm{mL}$ titer, diukur nilai $\mathrm{pH}$ campuran menggunakan $\mathrm{pH}$ meter hingga terjadi perubahan warna. Selanjutnya titrasi ini diganti dengan mengganti ekstrak bunga kalpataru dengan indikator fenoftalein sebagai pembanding.

\section{Titrasi Basa Lemah dan Asam Kuat}

$20 \mathrm{~mL}$ larutan $\mathrm{NH}_{4} \mathrm{OH} 0.1 \mathrm{M}$ dimasukkan ke dalam Erlenmeyer kemudian ditambahkan 5 tetes ekstrak bunga kalpataru hingga larutan berubah warna. Dititrasi dengan larutan $\mathrm{HCl} 0.1 \mathrm{M}$ 
hingga terjadi perubahan warna. Titrasi dilakukan sebanyak 3 kali dan mencatat volume titer yang digunakan. Setiap penambahan $2 \mathrm{~mL}$ titer, diukur nilai $\mathrm{pH}$ campuran menggunakan $\mathrm{pH}$ meter hingga terjadi perubahan warna. Selanjutnya titrasi ini diganti dengan mengganti ekstrak bunga kalpataru dengan indikator metil orange sebagai pembanding.

\section{Analisis Data}

Analisis data yang digunakan adalah deskriptif kualitatif meliputi uji sensoris terhadap perubahan warna ekstrak dan kertas indikator asam basa dari bunga kalpataru (Hura crepitans Linn) yang diuji pada larutan asam kuat $(\mathrm{HCl})$, asam lemah $\left(\mathrm{CH}_{3} \mathrm{COOH}\right)$, basa kuat $(\mathrm{NaOH})$, basa lemah $\left(\mathrm{NH}_{4} \mathrm{OH}\right)$ dan larutan buffer serta penentuan kurva titrasi melalui metode titrasi.

\section{Hasil dan Pembahasan}

\section{Ekstraksi Bunga Kalpataru}

Bunga kalpataru yang masih segar diekstraksi dengan metode maserasi menggunakan pelarut metanol selama \pm 2 jam. Ekstraksi adalah proses pemisahan komponen aktif dari suatu campuran padatan/cairan dengan menggunakan pelarut tertentu. Ada beberapa macam ekstraksi yang biasa digunakan pada proses pemisahan senyawa bioaktif dari tumbuhan yakni ekstraksi cara dingin yang terdiri dari maserasi, perkolasi dan sokletasi serta ekstraksi dengan cara panas yakni dengan cara refluks (Kiswandono, 2011).

Keuntungan proses ekstraksi dengan teknik maserasi caranya yang mudah dan tidak perlu pemanasan sehingga kecil kemungkinan bahan alam menjadi rusak atau terurai. Pemilihan pelarut berdasarkan kelarutan dan polaritasnya memudahkan pemisahan bahan alam dalam sampel (Susanti \& Bachmid, 2016). Pelarut yang bersifat polar dapat mengikat komponen senyawa fenolik termasuk flavonoid. Antosianin merupakan senyawa flavonoid yang bersifat polar dan akan larut pada pelarut polar. Metanol merupakan suatu senyawa yang memiliki struktur molekul $\mathrm{CH}_{3} \mathrm{OH}$, bersifat polar karena memiliki gugus hidroksil ($\mathrm{OH})$ dan juga bersifat non-polar karena memiliki gugus metil $\left(-\mathrm{CH}_{3}\right)$ (Ramdani dkk., 2017).

Ekstraksi menggunakan pelarut metanol memiliki rendemen paling tinggi (Romadanu dkk., 2014). Metanol dapat mengekstrak senyawa fitokimia dalam jumlah yang lebih banyak. Tingginya rendemen yang terdapat pada pelarut metanol menunjukkan pelarut tersebut mampu mengekstrak lebih banyak komponen bioaktif yang memiliki sifat kepolaran yang lebih tinggi. Hal ini diduga karena komponen bunga kalpataru mengandung antosianin (Supiyanti dkk., 2010).

Ekstrak kemudian didekantasi dan disaring untuk memisahkan fitrat dan residu. Dekantasi merupakan metode pemisahan campuran sederhana dengan cara menuangkan cairan secara perlahanlahan sehingga endapan tertinggal dibagian dasar wadah. Ekstrak yang diperoleh berwarna kuning

kecoklatan. Hal tersebut dapat menjadi indikasi bahwa bunga kalpataru mengandung antosianin. Antosianin merupakan pembentuk pigmen warna dasar pada tanaman.

\section{Uji Kualitatif Antosianin}

Hasil uji kualitatif antosianin ekstrak bunga kalpataru pada tabung I sebanyak $10 \mathrm{~mL}$ ekstrak dimasukkan kedalam tabung reaksi kemudian ditambahkan tetes demi tetes larutan $\mathrm{HCl} 2 \mathrm{M}$ lalu dipanaskan pada suhu $100{ }^{\circ} \mathrm{C}$ selama 5 menit, hasil yang diperoleh larutan berwarna merah tua. Sedangkan pada tabung II sebanyak $10 \mathrm{~mL}$ ekstrak dimasukkan kedalam tabung reaksi kemudian ditambahkan tetes demi tetes larutan $\mathrm{NaOH} 2 \mathrm{M}$, hasil yang diperoleh larutan berwarna hijau tua.

Uji positif antosianin ditandai dengan larutan berwarna merah dalam larutan asam dan berwarna hijau-memudar dalam larutan basa (Putri dkk., 2015). Ekstrak bunga kalpataru diindikasikan mengandung antosianin. Beberapa senyawa antosianin yang paling banyak ditemukan dialam adalah pelagornidin, peonidin, sianidin, malvidin, petunidin, dan delfinidin (Richana, 2009).

Antosianin tersusun dari sebuah aglikon (antosianidin) yang teresterifikasi dengan satu atau lebih gugus gula (glikon). Jenis antosianin yang tersebar didunia pertumbuhan yaitu pelagornidin berperan dalam warna orange, orange merah hingga merah tua, sedangkan sianidin berperan dalam warna orange merah, merah tua, merah keunguan, hingga merah kebiruan (Tensiska \& Natalia, 2007). Warna merah senduduk, lembayung dan biru umumnya disebabkan oleh delfidin yang gugus hidroksilnya lebih satu dibandingkan dengan sianidin (Harbone, 1987).

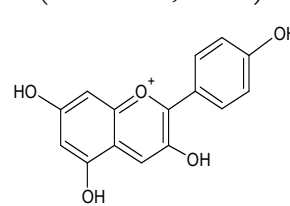

(Pelagornidin)<smiles></smiles>

(Peonidin)

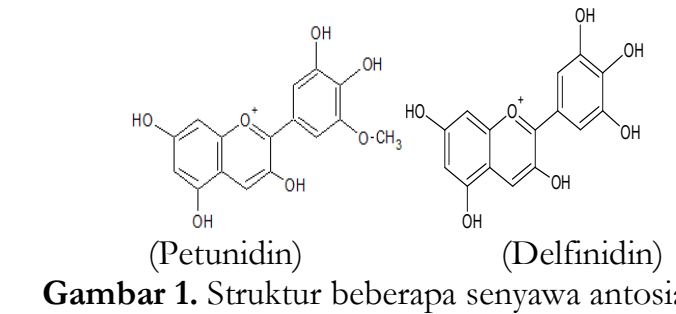

Gambar 1. Struktur beberapa senyawa antosianin (Priska dkk., 2018)

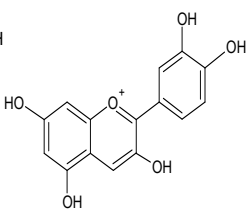

(Sianidin)

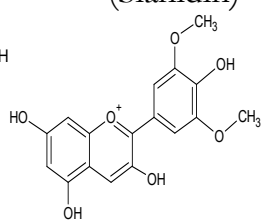

(Malvidin) 
Pengujian Ekstrak Indikator Bunga Kalpataru pada Latutan Asam Basa

Hasil pengujian ekstrak bunga kalpataru pada larutan asam-basa disajikan pada Gambar 2 dan Tabel 1.

Warna ekstrak bunga kalpataru yang diuji pada larutan asam kuat $(\mathrm{HCl} 0,1 \mathrm{M})$ berwarna merah, asam lemah $\left(\mathrm{CH}_{3} \mathrm{COOH}\right)$ berwarna merah muda, basa kuat $(\mathrm{NaOH})$ berwarna hijau tua dan basa lemah $\left(\mathrm{NH}_{4} \mathrm{OH}\right)$ berwarna hijau muda. Kemampuan berubah warna ekstrak bunga kalpataru pada kondisi asam dan basa tersebut dapat disebabkan oleh adanya antosianin. Antosianin pada $\mathrm{pH}$ asam berwarna merah atau ungu, sedangkan pada $\mathrm{pH}$ basa berwarna hijau atau kuning (Cevalloscasals \& Cisneros-zevallos, 2004). Antosianin adalah senyawa yang bersifat amfoter yaitu memiliki kemampuan untuk bereaksi baik dengan asam maupun dengan basa (Yudiono, 2011).

Antosianin dapat memiliki warna yang berbeda-beda, tergantung pada jumlah proton dilepas yang tetap melekat pada molekulnya. Antosianin merupakan asam organik lemah, sesuai dengan teori asam basa Lewis, asam adalah senyawa yang bertindak sebagai donor proton, dan bila telah melepaskan protonnya maka akan menjadi basa konjugasi. Antosianin adalah senyawa yang berdasarkan wujud asam basa konjugatnya akan menyerap dan memantulkan berbagai cahaya dengan panjang gelombang yang berbeda, sebagai akibatnya menyebabkan penampakan warna yang berbeda-beda pula (Santoso \& Wahyu, 2015).

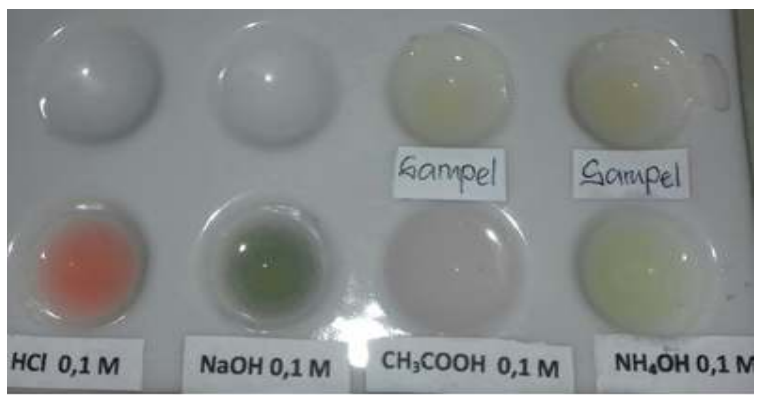

Gambar 2. Warna ekstrak indikator bunga kalpataru dalam larutan asam-basa.

Tabel 1. Hasil pengujian indikator ekstrak bunga kalpataru dalam larutan asam basa

\begin{tabular}{cc}
\hline Larutan & Warna Larutan Ekstrak Bunga Kalpataru \\
\hline Sampel & Kuning Kecoklatan \\
$\mathrm{HCl} \mathrm{0.1} \mathrm{M}$ & Merah \\
$\mathrm{NaOH} 0.1 \mathrm{M}$ & Hijau Tua \\
$\mathrm{CH}_{3} \mathrm{COOH} 0.1 \mathrm{M}$ & Merah Muda \\
$\mathrm{NH}_{4} \mathrm{OH} \mathrm{0.1} \mathrm{M}$ & Hijau Muda \\
\hline
\end{tabular}

\section{Pengujian Ekstrak Indikator Bunga Kalpataru pada Latutan Asam Basa}

Larutan buffer adalah larutan yang memiliki kemampuan untuk mempertahankan nilai $\mathrm{pH}$ ketika sejumlah asam/basa ditambahkan kedalam larutan penyangga tersebut. Larutan penyangga tersusun atas asam lemah dan basa konjugatnya atau basa lemah dan asam konjugatnya. Pengujian ekstrak indikator bunga kalpataru pada larutan buffer 1-12 bertujuan untuk mengetahui trayek $\mathrm{pH}$ dari indikator tersebut dengan cara meneteskan ekstrak indikator bunga kalpataru pada larutan buffer 1-12. Penggunaan ekstrak bunga kalptaru yang memberikan perubahan warna dapat dijadikan acuan dalam indikator titrasi asam-basa.

Hasil pengujian ekstrak bunga kalpataru pada larutan buffer $\mathrm{pH}$ 1-12 disajikan pada Gambar 3 dan Tabel 2.

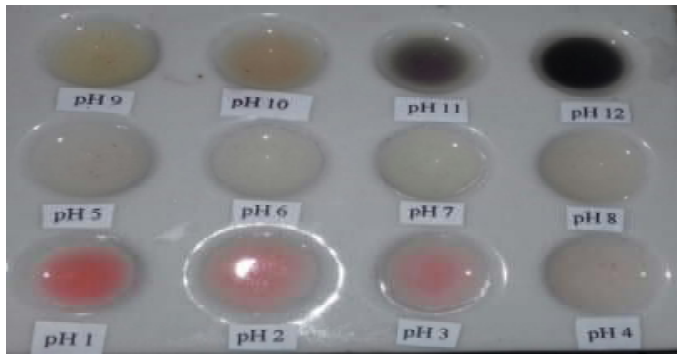

Gambar 3. Warna ekstrak indikator bunga kalpataru dalam larutan buffer $\mathrm{pH}$ 1-12. 
Tabel 2. Hasil pengujian indikator ekstrak bunga kalpataru

\begin{tabular}{cc} 
& dalam larutan buffer pH 1-12 \\
\hline Larutan Buffer & Warna Larutan Ekstrak Bunga Kalpataru \\
\hline pH 1 & Merah \\
pH 2 & Merah Muda \\
pH 3 & Merah Muda \\
pH 4 & Merah Muda \\
pH 5 & Tidak Berwarna \\
pH 6 & Tidak Berwarna \\
pH 7 & Tidak Berwarna \\
pH 8 & Tidak Berwarna \\
pH 9 & Hijau Kekuningan \\
pH 10 & Hijau Kekuningan \\
pH 11 & Hijau Tua \\
pH 12 & Hijau Tua \\
\hline
\end{tabular}

Antosianin dalam strukturnya mengandung kation flavilium, dapat terjadi perubahan warna karena terjadinya perubahan bentuk struktur dengan mengalami kesetimbangan membentuk senyawa anhidrobase yang disebabkan oleh pengaruh derajat keasaman (pH) (Yazid \& Munir, 2018). Bentuk kesetimbangan dan perubahan struktur dari senyawa antosianin pada berbagai kondisi $\mathrm{pH}$ dapat dilihat pada Gambar 4.

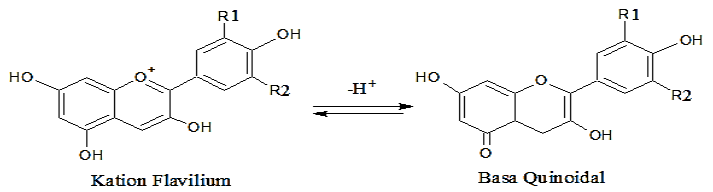

$\|+\mathrm{H}_{2} \mathrm{O}$

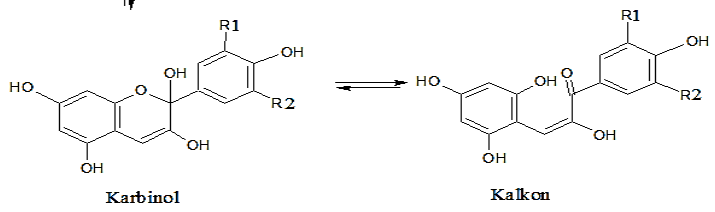

Gambar 4. Kesetimbangan antosianin dalam larutan (Rein, 2005)

Antosianin didalam larutan terdapat empat bentuk kesetimbangan yaitu kation flavilium, basa quinoidal, karbinol (pseudobase) dan kalkon (Bakowska-Barzak, 2005) Di bawah pH rendah, antosianin berada dalam bentuk kation flavilium merah. Saat $\mathrm{pH}$ dinaikkan ( $>5)$, akan mempercepat kehilangan proton sehingga membentuk basa quinoidal yang cenderung menjadi biru atau ungu, selain itu kenaikkan $\mathrm{pH}$ menyebabkan hidrasi kation flavilium untuk membentuk karbinol atau kalkon yang tidak berwarna (Rein, 2005).

\section{Pengujian pada Titrasi Asam Basa}

\section{Titrasi Asam Kuat dan Basa Kuat}

Data hasil penelitian titrasi asam kuat $(\mathrm{HCl}$ $0.1 \mathrm{M})$ dan basa kuat $(\mathrm{NaOH} 0.1 \mathrm{M})$ disajikan pada Tabel 3 dan 4.

Berdasarkan hasil penelitian penggunaan ekstrak indikator bunga kalpataru titik akhir titrasi yang diperoleh pada penambahan $20 \mathrm{~mL} \mathrm{NaOH} 0.1$ $\mathrm{M}$ dengan $\mathrm{pH}$ rata-rata 8.73 dan perubahan warna yang terjadi dari merah muda menjadi tidak berwarna pada titik akhir titrasi. Indikator pembanding yang digunakan yaitu indikator fenolftalein, titik akhir titrasi yang diperoleh pada penambahan $19.9 \mathrm{~mL} \mathrm{NaOH} 0.1 \mathrm{M}$ dengan $\mathrm{pH}$ rata-rata 8.78 dan perubahan warna yang terjadi dari tidak berwarna menjadi berwarna ungu.

Hasil dari penggunaan indikator ekstrak bunga kalpataru dan indikator fenolftalein sebagai pembanding disajkan pada kurva yang terdapat pada Gambar 5.

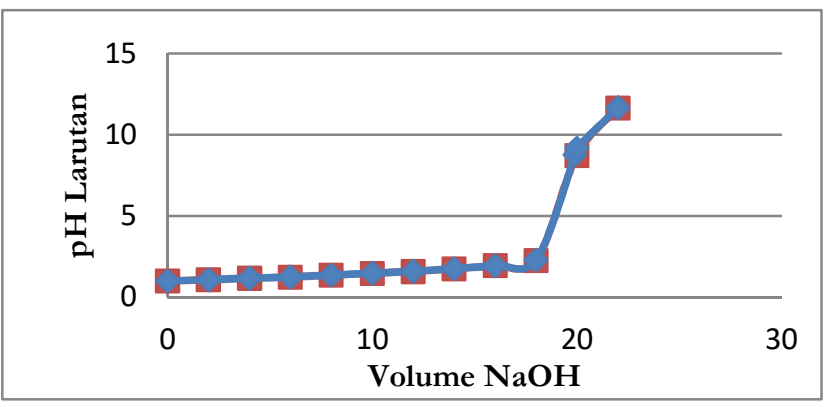

Gambar 5. Kurva titrasi asam kuat dan basa kuat. (- - ekstrak bunga kalpataru, $\stackrel{\star}{*}$ indikator fenolftalein) 
Tabel 3. Data hasil titrasi $20 \mathrm{~mL} \mathrm{HCl} 0.1 \mathrm{M}$ dan $\mathrm{NaOH} 0.1 \mathrm{M}$ dengan indikator ekstrak bunga kalpataru

\begin{tabular}{|c|c|c|c|c|c|c|}
\hline \multirow{2}{*}{ No. } & \multirow{2}{*}{$\begin{array}{c}\text { Volume } \mathrm{NaOH} \\
(\mathrm{mL})\end{array}$} & \multicolumn{3}{|c|}{ Titrasi pH ke } & \multirow{2}{*}{$\mathrm{pH}$ rata-rata } & \multirow{2}{*}{ Perubahan warna } \\
\hline & & 1 & 2 & 3 & & \\
\hline 1. & 0 & 1.01 & 1.01 & 1.02 & 1.01 & Merah Muda \\
\hline 2. & 2 & 1.09 & 1.08 & 1.09 & 1.09 & Merah Muda \\
\hline 3. & 4 & 1.18 & 1.17 & 1.16 & 1.17 & Merah Muda \\
\hline 4. & 6 & 1.25 & 1.27 & 1.26 & 1.26 & Merah Muda \\
\hline 5. & 8 & 1.36 & 1.38 & 1.37 & 1.37 & Merah Muda \\
\hline 6. & 10 & 1.48 & 1.48 & 1.48 & 1.48 & Merah Muda \\
\hline 7. & 12 & 1.61 & 1.60 & 1.59 & 1.60 & Merah Muda \\
\hline 8. & 14 & 1.76 & 1.73 & 1.78 & 1.76 & Merah Muda \\
\hline 9. & 16 & 1.96 & 1.94 & 1.94 & 1.95 & Merah Muda \\
\hline 10. & 18 & 2.25 & 2.26 & 2.27 & 2.26 & Merah Muda \\
\hline 11. & 20 & 8.70 & 8.73 & 8.76 & 8.73 & Tidak berwarna \\
\hline 12. & 22 & 11.66 & 11.64 & 11.68 & 11.66 & Tidak berwarna \\
\hline
\end{tabular}

Tabel 4. Data hasil titrasi $20 \mathrm{~mL} \mathrm{HCl} 0.1 \mathrm{M}$ dan $\mathrm{NaOH} 0.1 \mathrm{M}$ dengan indikator fenolftalein

\begin{tabular}{ccccccc}
\hline \multirow{2}{*}{ No. } & $\begin{array}{c}\text { Volume NaOH } \\
(\mathrm{mL})\end{array}$ & \multicolumn{3}{c}{ Titrasi $\mathrm{pH}$ ke } & \multirow{2}{*}{$\mathrm{pH}$ rata-rata } & Perubahan warna \\
\cline { 3 - 5 } & 0 & 1.02 & 1.02 & 1.03 & 1.02 & Tidak berwarna \\
\hline 1. & 2 & 1.07 & 1.09 & 1.08 & 1.08 & Tidak berwarna \\
2. & 4 & 1.19 & 1.18 & 1.17 & 1.18 & Tidak berwarna \\
3. & 6 & 1.26 & 1.25 & 1.25 & 1.25 & Tidak berwarna \\
4. & 8 & 1.36 & 1.38 & 1.37 & 1.37 & Tidak berwarna \\
5. & 10 & 1.49 & 1.47 & 1.50 & 1.49 & Tidak berwarna \\
6. & 12 & 1.61 & 1.61 & 1.60 & 1.61 & Tidak berwarna \\
7. & 14 & 1.78 & 1.78 & 1.75 & 1.77 & Tidak berwarna \\
8. & 16 & 1.98 & 1.96 & 1.93 & 1.96 & Tidak berwarna \\
9. & 18 & 2.30 & 2.29 & 2.27 & 2.29 & Tidak berwarna \\
10. & 19.9 & 8.78 & 8.77 & 8.79 & 8.78 & Ungu \\
11. & 20 & 9.20 & 9.21 & 9.19 & 9.20 & Ungu \\
12. & 22 & 11.68 & 11.69 & 11.67 & 11.68 & Ungu \\
13. & & & & & & \\
\hline
\end{tabular}

Kurva titrasi asam kuat dan basa kuat yang menggunakan ekstrak bunga kalpataru sebagai indikator dengan indikator fenolftalein sebagai pembanding, bahwa pada penambahan larutan $\mathrm{NaOH} 0.1 \mathrm{M}$ dari volume $0-22 \mathrm{~mL}$, kedua garis kurva tidak jauh berbeda dan cenderung berimpitan menunjukkan bahwa nilai $\mathrm{pH}$ yang diperoleh dari kedua indikator tersebut tidak jauh berbeda. Hal ini mengindikasikan bahwa penggunaan indikator ekstrak bunga kalpataru dapat digunakan untuk titrasi asam kuat dan basa kuat.

\section{Titrasi Asam Lemah dan Basa Kuat}

Data hasil penelitian titrasi asam lemah $\left(\mathrm{CH}_{3} \mathrm{COOH} 0.101 \mathrm{M}\right)$ dan basa kuat $(\mathrm{NaOH} 0.1 \mathrm{M})$ dapat dilihat pada Tabel 5 dan 6 . 
Tabel 5. Data hasil titrasi $20 \mathrm{~mL} \mathrm{CH}_{3} \mathrm{COOH} 0.1 \mathrm{M}$ dan $\mathrm{NaOH} 0.1 \mathrm{M}$ dengan indikator ekstrak bunga kalpataru

\begin{tabular}{|c|c|c|c|c|c|c|}
\hline \multirow{2}{*}{ No. } & \multirow{2}{*}{ Volume $\mathrm{NaOH}(\mathrm{mL})$} & \multicolumn{3}{|c|}{ Titrasi pH ke } & \multirow{2}{*}{$\mathrm{pH}$ rata-rata } & \multirow{2}{*}{ Perubahan warna } \\
\hline & & 1 & 2 & 3 & & \\
\hline 1. & 0 & 2.86 & 2.86 & 2.88 & 2.87 & Merah Muda \\
\hline 2. & 2 & 3.77 & 3.78 & 3.76 & 3.77 & Tidak berwarna \\
\hline 3. & 4 & 4.14 & 4.15 & 4.16 & 4.15 & Tidak berwarna \\
\hline 4. & 6 & 4.38 & 4.36 & 4.38 & 4.37 & Tidak berwarna \\
\hline 5. & 8 & 4.55 & 4.57 & 4.56 & 4.56 & Tidak berwarna \\
\hline 6. & 10 & 4.74 & 4.72 & 4.76 & 4.74 & Tidak berwarna \\
\hline 7. & 12 & 4.90 & 4.91 & 4.91 & 4.91 & Tidak berwarna \\
\hline 8. & 14 & 5.08 & 5.10 & 5.09 & 5.09 & Tidak berwarna \\
\hline 9. & 16 & 5.34 & 5.36 & 5.35 & 5.35 & Tidak berwarna \\
\hline 10 . & 18 & 5.67 & 5.68 & 5.66 & 5.67 & Tidak berwarna \\
\hline 11. & 20 & 6.75 & 6.74 & 6.74 & 6.74 & Tidak berwarna \\
\hline 12. & 20.2 & 9.10 & 9.09 & 9.08 & 9.09 & Kuning \\
\hline 13. & 22 & 11.63 & 11.64 & 11.62 & 11.63 & Kuning \\
\hline
\end{tabular}

Berdasarkan hasil penelitian penggunaan ekstrak indikator bunga kalpataru titik akhir titrasi yang diperoleh pada penambahan $20.2 \mathrm{~mL} \mathrm{NaOH}$ $0.1 \mathrm{M}$ dengan $\mathrm{pH}$ rata-rata 9.09 dan perubahan warna yang terjadi dari merah muda menjadi kuning pada titik akhir titrasi. Indikator pembanding yang digunakan yaitu indikator fenolftalein, titik akhir titrasi yang diperoleh pada penambahan $20.1 \mathrm{~mL}$ $\mathrm{NaOH} 0.1 \mathrm{M}$ dengan $\mathrm{pH}$ rata-rata 9.15 dan perubahan warna yang terjadi dari tidak berwarna menjadi berwarna ungu. Hasil dari penggunaan indikator ekstrak bunga kalpataru dan indikator fenolftalein sebagai pembanding dapat dilihat pada kurva yang terdapat pada Gambar 6.

Tabel 6. Data hasil titrasi $20 \mathrm{~mL} \mathrm{CH}_{3} \mathrm{COOH} 0.1 \mathrm{M}$ dan $\mathrm{NaOH} 0.1 \mathrm{M}$ dengan indikator fenolftalein

\begin{tabular}{|c|c|c|c|c|c|c|}
\hline \multirow{2}{*}{ No. } & \multirow{2}{*}{ Volume $\mathrm{NaOH}(\mathrm{mL})$} & \multicolumn{3}{|c|}{ Titrasi pH ke } & \multirow{2}{*}{$\mathrm{pH}$ rata-rata } & \multirow{2}{*}{ Perubahan warna } \\
\hline & & 1 & 2 & 3 & & \\
\hline 1. & 0 & 2.84 & 2.89 & 2.80 & 2.84 & Tidak berwarna \\
\hline 2. & 2 & 3.79 & 3.78 & 3.75 & 3.77 & Tidak berwarna \\
\hline 3. & 4 & 4.13 & 4.15 & 4.15 & 4.14 & Tidak berwarna \\
\hline 4. & 6 & 4.39 & 4.38 & 4.38 & 4.38 & Tidak berwarna \\
\hline 5. & 8 & 4.58 & 4.58 & 4.60 & 4.59 & Tidak berwarna \\
\hline 6. & 10 & 4.74 & 4.78 & 4.76 & 4.76 & Tidak berwarna \\
\hline 7. & 12 & 4.92 & 4.90 & 4.94 & 4.91 & Tidak berwarna \\
\hline 8. & 14 & 5.11 & 5.09 & 5.10 & 5.10 & Tidak berwarna \\
\hline 9. & 16 & 5.36 & 5.38 & 5.36 & 5.37 & Tidak berwarna \\
\hline 10. & 18 & 5.68 & 5.69 & 5.68 & 5.68 & Tidak berwarna \\
\hline 11. & 20 & 6.76 & 6.73 & 6.70 & 6.73 & Tidak berwarna \\
\hline 12. & 20.1 & 9.13 & 9.16 & 9.17 & 9.15 & Ungu \\
\hline 13. & 22 & 11.63 & 11.69 & 11.65 & 11.66 & Ungu \\
\hline
\end{tabular}

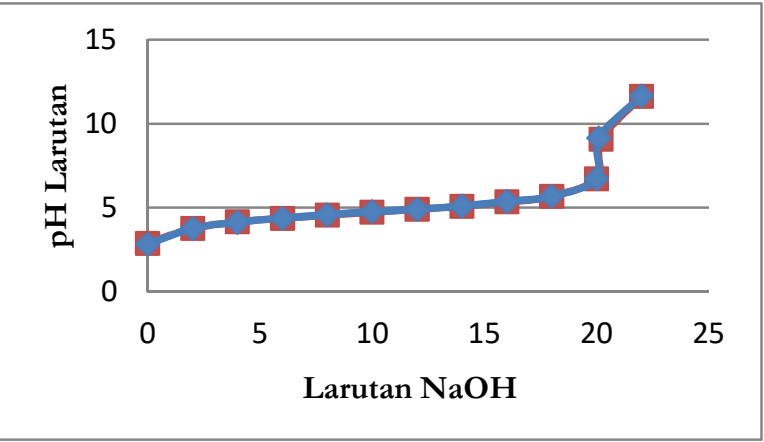

Gambar 6. Kurva titrasi asam lemah dan basa kuat (-ekstrak bunga kalpataru, $\approx$ indikator fenolftalein) 
Kurva titrasi asam lemah dan basa kuat yang menggunakan ekstrak bunga kalpataru sebagai indikator dengan indikator fenolftalein sebagai pembanding, bahwa pada penambahan larutan $\mathrm{NaOH}$ 0.1 M dari volume $0-22 \mathrm{~mL}$, kedua garis kurva tidak jauh berbeda dan cenderung berimpitan yang menunjukkan bahwa nilai $\mathrm{pH}$ yang diperoleh dari kedua indikator tersebut tidak jauh berbeda pula. Hal ini mengindikasikan bahwa penggunaan indikator ekstrak bunga kalpataru dapat digunakan untuk titrasi asam lemah dan basa kuat.

Indikator fenolftalein merupakan indikator yang sering digunakan dalam titrasi asam basa. Fenolftalein memberikan perubahan warna dari tak berwarna dalam larutan asam menjadi merah muda atau ungu dalam larutan basa. Secara teori rentang $\mathrm{pH}$ perubahan indikator fenolftalein berada pada kisaran 8.0-9.60 (Day \& Underwood, 2002). Hal tersebut membuktikan bahwa rentang $\mathrm{pH}$ perubahan warna ekstrak bunga kalpataru masih berada pada rentang perubahan $\mathrm{pH}$ indikator fenolftalein.

\section{Titrasi Basa Lemah dan Asam Kuat}

Data hasil penelitian titrasi basa lemah $\left(\mathrm{NH}_{4} \mathrm{OH} 0.1 \mathrm{M}\right)$ dan asam kuat $(\mathrm{HCl} 0.1 \mathrm{M})$ dapat dilihat pada Tabel 7 dan 8 .

Berdasarkan hasil penelitian penggunaan ekstrak indikator bunga kalpataru titik akhir titrasi yang diperoleh pada penambahan $20 \mathrm{~mL} \mathrm{HCl} \mathrm{0.1} \mathrm{M}$ dengan $\mathrm{pH}$ rata-rata 3.62 dan perubahan warna yang terjadi dari kuning menjadi orange pada titik akhir titrasi. Indikator pembanding yang digunakan yaitu indikator metil orange, titik akhir titrasi yang diperoleh pada penambahan $19.9 \mathrm{~mL} \mathrm{HCl} \mathrm{0.1} \mathrm{M}$ dengan $\mathrm{pH}$ rata-rata 3.68 dan perubahan warna yang terjadi dari kuning menjadi orange. Secara teori rentang $\mathrm{pH}$ indikator metil orange berada pada kisaran 3.1-4.4 (Day \& Underwood, 2002).

Hal tersebut membuktikan bahwa rentang pH perubahan warna ekstrak bunga kalpataru masih berada pada rentang perubahan $\mathrm{pH}$ indikator metil orange. Hasil dari penggunaan indikator ekstrak bunga kalpataru dan indikator metil orange sebagai pembanding dapat dilihat pada kurva yang terdapat pada Gambar 7.

Kurva titrasi basa lemah dan asam kuat yang menggunakan ekstrak bunga kalpataru sebagai indikator dengan indikator metil orange sebagai pembanding, bahwa pada penambahan larutan $\mathrm{HCl}$ $0.1 \mathrm{M}$ dari volume $0-22 \mathrm{~mL}$, kedua garis kurva tidak jauh berbeda dan cenderung berimpitan yang menunjukkan bahwa nilai $\mathrm{pH}$ yang diperoleh dari kedua indikator tersebut tidak jauh berbeda pula. $\mathrm{Hal}$ ini mengindikasikan bahwa penggunaan indikator ekstrak bunga kalpataru dapat digunakan untuk titrasi basa lemah dan asam kuat.

Senyawa senyawa organik yang dapat digunakan sebagai indikator dalam titrasi mempunyai karakteristik yaitu senyawa memberikan perubahan warna terhadap perubahan suasana $\mathrm{pH}$ larutan. Perubahahan warna dapat terjadi melalui proses kesetimbangan bentuk molekul dan ion dari senyawa indikator tersebut (Nuryanti dkk., 2010).

Tabel 7. Data hasil titrasi $20 \mathrm{~mL} \mathrm{NH}_{4} \mathrm{OH} 0.1 \mathrm{M}$ dan $\mathrm{HCl} 0.1 \mathrm{M}$ dengan indikator ekstrak bunga kalpataru

\begin{tabular}{|c|c|c|c|c|c|c|}
\hline \multirow{2}{*}{ No. } & \multirow{2}{*}{ Volume $\mathrm{HCl}(\mathrm{mL})$} & \multicolumn{3}{|c|}{ Titrasi $\mathrm{pH}$ ke } & \multirow{2}{*}{$\mathrm{pH}$ rata-rata } & \multirow{2}{*}{ Perubahan warna } \\
\hline & & 1 & 2 & 3 & & \\
\hline 1. & 0 & 11.03 & 11.02 & 11.02 & 11.02 & Kuning \\
\hline 2. & 2 & 9.96 & 9.94 & 9.90 & 9.93 & Kuning \\
\hline 3. & 4 & 9.59 & 9.57 & 9.57 & 9.58 & Kuning \\
\hline 4. & 6 & 9.37 & 9.35 & 9.37 & 9.36 & Kuning \\
\hline 5. & 8 & 9.15 & 9.15 & 9.19 & 9.16 & Kuning \\
\hline 6. & 10 & 9.03 & 9.01 & 9.0 & 9.01 & Kuning \\
\hline 7. & 12 & 8.83 & 8.83 & 8.84 & 8.83 & Kuning \\
\hline 8. & 14 & 8.60 & 8.64 & 8.61 & 8.62 & Kuning \\
\hline 9. & 16 & 8.35 & 8.42 & 8.36 & 8.38 & Kuning \\
\hline 10. & 18 & 8.08 & 8.02 & 8.04 & 8.05 & Kuning \\
\hline 11. & 20 & 3.60 & 3.64 & 3.63 & 3.62 & Orange \\
\hline 12. & 22 & 2.29 & 2.32 & 2.32 & 2.31 & Orange \\
\hline
\end{tabular}




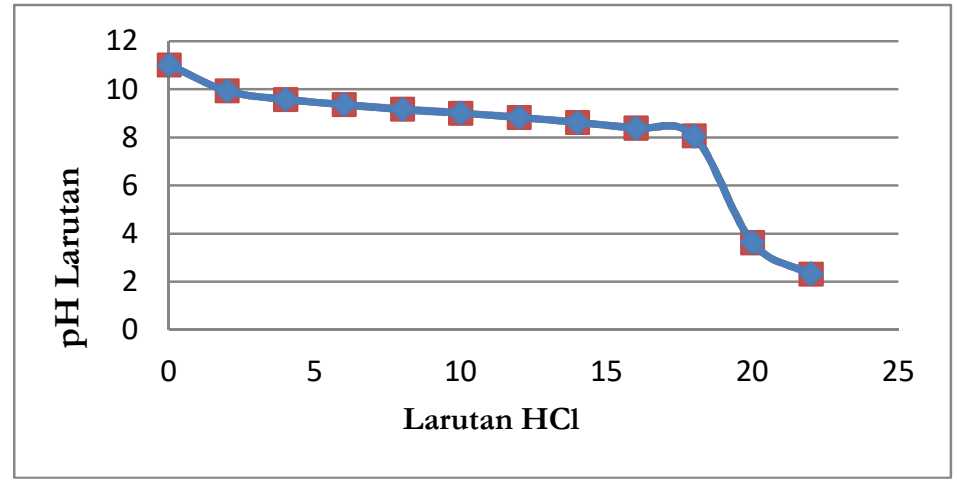

Gambar 7. Kurva titrasi basa lemah dan asam kuat $(-$ ekstrak bunga kalpataru, $\leadsto$ indikator metil orange)

Tabel 8. Data hasil titrasi $20 \mathrm{~mL} \mathrm{NH}_{4} \mathrm{OH} 0.1 \mathrm{M}$ dan $\mathrm{HCl} 0.1 \mathrm{M}$ dengan indikator metil orange

\begin{tabular}{ccccccc}
\hline \multirow{2}{*}{ No. } & \multirow{2}{*}{ Volume $\mathrm{HCl}(\mathrm{mL})$} & \multicolumn{3}{c}{ Titrasi ke $\mathrm{pH}$ ke } & \multirow{2}{*}{ pH rata-rata } & Perubahan \\
\cline { 3 - 4 } warna
\end{tabular}

\section{Kesimpulan}

Ekstrak bunga kalpataru (Hura crepitans Linn) dapat digunakan sebagai indikator asam-basa alternatif dan berdasarkan data kurva titrasi yang diperoleh jenis titrasi asam-basa yang tepat digunakan pada ekstrak bunga kalpataru adalah pada titrasi asam kuat-basa kuat dan asam lemah-basa kuat sebagai alternatif pengganti indikator fenolftalein sedangkan pada titrasi basa lemah-asam kuat baik digunakan untuk pengganti indikator metil orange.

\section{Ucapan Terima Kasih}

Penulis menyampaikan terima kasih kepada pihak-pihak yang telah membantu dalam penyelesaian studi.

\section{Referensi}

Agustiani, W. (2015). Kandungan fitokimia kalpataru (Hura crepitans Linn) sebagai rekomendasi jenis tanaman butan kota berkhasiat obat. Skripsi Tidak Diterbitkan. Bogor: Institut Pertanian Bogor.
Bakowska-Barzak, A. (2005). Acylated anthocyanins as stable, natural food colorants - A review. Polish Journal of Food and Nutrition Sciences, 14(2), 107-115.

Bridgers, E. N., Chinn, M. S., \& Truong, V. (2010). Extraction of anthocyanins from industrial purple-fleshed sweetpotatoes and enzymatic hydrolysis of residues for fermentable sugars. Industrial Crops \& Products, 32(3), 613-620.

Cevallos-casals, A., \& Cisneros-zevallos, L. (2004). Food chemistry stability of anthocyanin-based aqueous extracts of andean purple corn and red-fleshed sweet potato compared to synthetic and natural colorants. Food Chemistry, 86(1), 69-77.

Day, R. A., \& Underwood, A. L. (2002). Analisis kimia kuantitatif. Jakarta: Erlangga

Dewi, J. R., Estiasih, T., \& Murtini, S. (2002). Aktivitas antioksidan dedak sorgum lokal varietas coklat (sorghum bicolor) hasil ekstrasi berbagai pelarut. Jurnal Teknologi Pertanian, 8(3), 188-197. 
Fessenden, R. J., \& Fessenden, J. S. (1999). Kimia organik jilid 2. Jakarta: Erlangga

Harbone, F. G. (1987). Metode fitokimia. Bandung: Institut Teknologi Bandung

Indira, C. (2015). Pembuatan indikator asam basa karamunting. Kaunia, 11(1), 1-10.

Kiswandono, A. A. (2011). Skrining senyawa kimia dan pengaruh metode maserasi dan refluks pada biji kelor (moringa oleifera, lamk) terhadap rendemen ekstrak yang dihasilkan. Jurnal Sains Natural Universitas Nusa Bangsa, 1(2), 126-134.

Lestari, P. (2016). Kertas indikator bunga belimbing wuluh (averrhoa bilimbi l) untuk uji larutan asam basa. Jurnal Pendidikan Madrasah, 1(1), 6984.

Moss, B. W. (2002). Colour in food. D. B Macdougall (ed), The chemistry of food colour (pp 145 - 178). Washington: CRC Press.

Nuryanti, S., Matsjeh, S., Anwar, C., \& Raharjo, T. J. (2010). Indikator titrasi asam-basa dari ekstrak bunga sepatu (hibiscus rosa sinensis 1). Agritech, 30(3), 178-183.

Perry, R. H. (1999). Perry's chemical engineer's handbook (7th ed.). New York: McGraw-Hill Company.

Priska, M., Peni, N., Carvallo, L., \& Ngapa, Y. D. (2018). Review: Antosianin dan pemanfaatannya. E-Journal of Applied Chemistry, 6(2), 79-97.

Putri, N. K. M., Gunawan, I. W. G., \& Suarsa, I. W. (2015). Aktivitas antioksidan antosianin dalam ekstrak etanol kulit buah naga super merah (hylocereus costaricensis) dan analisis kadar totalnya. Jurnal Kimia, 9(2), 243-251.

Ramdani, D., Marjuki, \& Chuzaemi, S. (2017). Pengaruh perbedaan jenis pelarut dalam proses ekstraksi buah mengkudu (morinda citrifolia l.) pada pakan terhadap viabilitas protozoa dan produksi gas in-vitro. Jurnal Ilmu-Imu Peternakan, 27(2), 54-62.

Rein, M. (2005). Copigmentation reactions and color stability of berry anthocyanin. Disertasi Tidak Diterbitkan. Finlandia: University of Helsinki.

Richana, N. (2009). Ubi kayu dan ubu jalar. Bogor: Nuansa Cendikia

Romadanu., Rachmawati, S. H., \& Lestari, S. D. (2014). Pengujian aktivitas antioksidan ekstrak bunga lotus (nelumbo nucifera). Fistech, 3(1), 17.

Santoso, B., \& Wahyu, E. S. M. (2015). Penapisan zat warna alam golongan anthocyanin dari tanaman sekitar sebagai indikator asam basa. Jurnal Fluida, 11(2), 1-8.

Supiyanti, W., Wulansari, E. D., \& Kusnita, L. (2010). Uji aktivitas antiosidan dan penentuan kandungan antosianin total kulit buah manggis (garcinia mangostana 1). Majalab Obat Tradisional, 15(2), 64-70.

Susanti, \& Bachmid, F. (2016). Perbandingan metode ekstraksi maserasi dan refluks terhadap kadar fenolik dari ekstrak tongkol jagung (zea mays 1.). Jurnal Konversi, 5(2), 87-93.

Tensiska, Sukarminah, E., \& Natalia, D. (2007). Ekstraksi pewarna alami dari buah arben (rubus idaeus linn) dan aplikasi pada sistem pangan. Jurnal Teknologi dan Industri Pangan, 18(1), 25-31.

Yazid, E. A., \& Munir, M. M. (2018). Potensi antosianin dari ekstrak bunga rosella (hibischus sabdariffa l) sebagai alternatif indikator titrasi asam basa. Jurnal Sains, 8(15), 1-7.

Yudiono, K. (2011). Ekstraksi antosianin dari ubi jalar ungu (ipomoea batatas cv ayamurasaki) dengan teknik ekstraksi subritical water. Jurnal Teknologi Pangan, 2(1), 1-30. 